\title{
Human papillomavirus type 16 causes a defined subset of conjunctival in situ squamous cell carcinomas
}

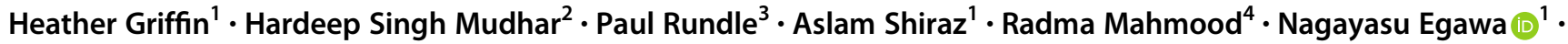 \\ Wim Quint ${ }^{5} \cdot$ Ian G. Rennie ${ }^{3} \cdot$ John Doorbar ${ }^{1}$
}

Received: 20 May 2019 / Revised: 16 July 2019 / Accepted: 16 July 2019 / Published online: 4 September 2019

(c) United States \& Canadian Academy of Pathology 2019

\begin{abstract}
Squamous cell carcinoma of the conjunctiva is associated with a number of risk factors, including HIV infection, iatrogenic immunosuppression and atopy. In addition, several studies have suggested an involvement of HPV, based on the presence of viral DNA, but did not establish whether there was active infection or evidence of causal disease association. In this manuscript, 31 cases of conjunctival in situ squamous cell carcinoma were classified as HPV DNA-positive or -negative, before being analysed by immunohistochemistry to establish the distribution of viral and cellular biomarkers of HPV gene expression. Our panel included p16 ${ }^{\mathrm{INK} 4 \mathrm{a}}$, TP53 and MCM, but also the virally encoded E4 gene product, which is abundantly expressed during productive infection. Subsequent in situ detection of HPV mRNA using an RNAscope approach confirmed that early HPV gene expression was occurring in the majority of cases of HPV DNA-positive conjunctival in situ squamous cell carcinoma, with all of these cases occurring in the atopic group. Viral gene expression correlated with TP53 loss, p16 ${ }^{\mathrm{INK} 4 \mathrm{a}}$ elevation, and extensive MCM expression, in line with our general understanding of E6 and E7's role during transforming infection at other epithelial sites. A characteristic E4 expression pattern was detected in only one case. HPV mRNA was not detected in lower grades of dysplasia, and was not observed in cases that were HPV DNA-negative. Our study demonstrates an active involvement of HPV in the development of a subset of conjunctival in situ squamous cell carcinoma. No high-risk HPV types were detected other than HPV16. It appears that the conjunctiva is a vulnerable epithelial site for HPV-associated transformation. These cancers are defined by their pattern of viral gene expression, and by the distribution of surrogate markers of HPV infection.
\end{abstract}

John Doorbar

jd121@cam.ac.uk

1 Department of Pathology, University of Cambridge, Tennis Court Road, Cambridge CB2 1QP, UK

2 National Specialist Ophthalmic Pathology Service, Department of Histopathology, E-Floor, Royal Hallamshire Hospital, Glossop Rd, Sheffield S10 2JF, UK

3 Sheffield Ocular Oncology Service, Department of Ophthalmology, Royal Hallamshire Hospital, Glossop Rd, Sheffield S10 2JF, UK

4 Francis Crick Institute, Mill Hill Laboratory, The Ridgeway, Mill Hill, London NW7 1AA, UK

5 Delft Diagnostic Laboratories, Visseringlaan 25, 2288 ER Rijswijk, The Netherlands

\section{Introduction}

The conjunctival epithelium can give rise to squamous dysplasia, carcinoma in situ and invasive squamous carcinoma. Two disease patterns occur. The first shows an incidence that is highest in the Southern Hemisphere ( $16^{\circ}$ South), particularly in Africa, with a mean age of 40 years. Elsewhere, conjunctival squamous neoplasia affects older adults with a mean age of occurrence at around 60 years, and is found more often in men (70\%) than women. The Age Standardised Rate (ASR) worldwide is 0.18 and 0.08 cases/year/100,000 among males and females respectively, but can be as high as 19 cases/year/100,000 in some locations [1]. Lifelong exposure to ultraviolet light is considered to be the major aetiological factor in the development of conjunctival squamous neoplasia, along with outdoor occupations. Meta-analysis has also shown an association with HIV and HPV, iatrogenic immunosuppression post-organ transplantation, as well as atopic 
eczema but not cigarette smoking. The effect of Xeroderma pigmentosum and vitamin A deficiency is unclear [2]. African women probably have increased risk of conjunctival squamous neoplasia due to the higher prevalence of HIV and HPV infections. It is generally expected that the incidence of conjunctival squamous neoplasia will increase in coming years, as anti-retroviral therapy does not impact on the disease incidence, and because the number of individuals living with HIV infections will increase. A contributory role of atopy in the development of conjunctival squamous neoplasia has also been suggested [3]. The appearance of conjunctival squamous neoplasia in asthmatic individuals occurs at a younger age than normally expected, is more likely to occur bilaterally and is generally more aggressive.

The human papillomaviruses (HPV) are a large and heterogeneous group of small non-enveloped DNA viruses that complete their life cycle in a range of different epithelial tissues. They are often referred to as either low- or high risk depending on their tumourogenic potential. Cervical cancer is the most prevalent cancer caused by high-risk HPV (HRHPV), but HPV-associated cancers also occur at other vulnerable epithelial sites, including the anus and oropharynx. Papillomaviruses display an extreme level of adaptation to the regulatory mechanisms governing keratinocyte differentiation, with viral genes being sequentially activated during this process [4]. Thus the HR-HPV E6 and E7 gene products stimulate cell proliferation in the lower epithelial layers, but also ensure that differentiating cells undergo cell cycle entry to facilitate viral genome amplification in the upper epithelial layers [4, 5]. Viral proteins involved in replication and transmission, such as $\mathrm{E} 4$, accumulate in these differentiating cells to support virus assembly and the eventual release of infectious virions from the superficial cell layers [4]. Our current thinking suggest that the levels and activity of E6 and E7 are tightly regulated in such productive infections, where basaloid cells occupy the lower third of epithelium, but can become deregulated in high-grade squamous-intraepithelial lesions or moderate to severe dysplasia [5]. Viral gene expression underlies the pathology of both low- and high-grade cervical squamous-intraepithelial lesions, and can predispose the infected cell to the accumulation of genetic errors and the eventual progression to cancer [5]. These effects are a consequence of E6 and E7's interaction with a plethora of host-encoded proteins, of which TP53 and members of the pRb pocket protein family are most thoroughly characterised [6,7]. When expressed together, host cell proteins that are normally regulated by $\mathrm{pRb}$, including $\mathrm{p} 16^{\mathrm{INK} 4 \mathrm{a}}, \mathrm{MCM}$ (minichromosome maintenance), and Ki-67, can be used as surrogate markers of viral gene expression [6-8], and are expressed throughout the epithelial layers in high-grade cervical neoplasia and cancer $[9,10]$. In low-grade cervical lesions, such proteins are typically confined to the lower epithelial layers.
Although HR-HPV DNA has been reported to be present in dysplastic and malignant lesions of the conjunctiva and lacrimal sac, the presence of viral DNA does not necessarily confirm an active role for the virus as the cause of the lesion. HPV DNA detection is often combined with immunohistochemistry for $\mathrm{p} 16^{\mathrm{INK} 4 \mathrm{a}}$ and/or Ki-67 [11-14], although these markers can also be detected in cells undergoing metaplasia and senescence. Here we combine standard HPV DNA typing, with immunohistochemistry and an in situ mRNA staining technique able to detect HPVE6 and -E7 gene expression in biopsies taken from patients either with conjunctival in situ squamous carcinoma, and with lower grade dysplasia, in order to clarify the role of HPV in conjunctival squamous neoplasia. Our data reveal that a subset of conjunctival in situ squamous carcinomas have a clear HPV involvement, with a deregulated pattern of HPV gene expression comparable with that seen in highgrade squamous-intraepithelial lesions at other sites. Only in one of the conjunctival in situ squamous carcinoma cases examined was there evidence of productive infection and the expression of $\mathrm{E} 4$, suggesting that the corneal limbus and conjunctiva are primarily sites of abortive HPV infection. This study confirms that the conjunctiva is one of the vulnerable epithelial sites where high-risk HPV infection can lead to the development of precancerous lesions.

\section{Materials and methods}

\section{Clinical samples}

Conjunctival biopsies with a diagnosis of in situ squamous carcinoma, and lower grades of squamous dysplasia, were obtained from the National Specialist Ophthalmic Pathology Service Histopathology archive from the Royal Hallamshire Hospital, Sheffield. These diagnostic biopsies were performed as part of the routine clinical management of patients presenting with a mass on the conjunctiva. Biopsies were fixed in standard $10 \%$ buffered formalin and processed to paraffin. Four micrometre sections were cut and stained with standard haematoxylin and eosin for conventional light microscopic diagnostic interpretation. Additional sections were used for in situ hybridisation, immunohistochemistry or immunofluorescence analysis; with three sections taken for whole tissue section-PCR HPV genotyping (as described previously [14]). To avoid cross-contamination, a fresh new disposable blade was used for sectioning, and the microtome was cleaned between each block using DNAzap. All protocols were approved by local ethics committees (Study approved by Sheffield Teaching Hospitals clinical research office under the Ophthalmology tissue bank, number STH15427 with sub study numbers: STH18647 and STH19306). 


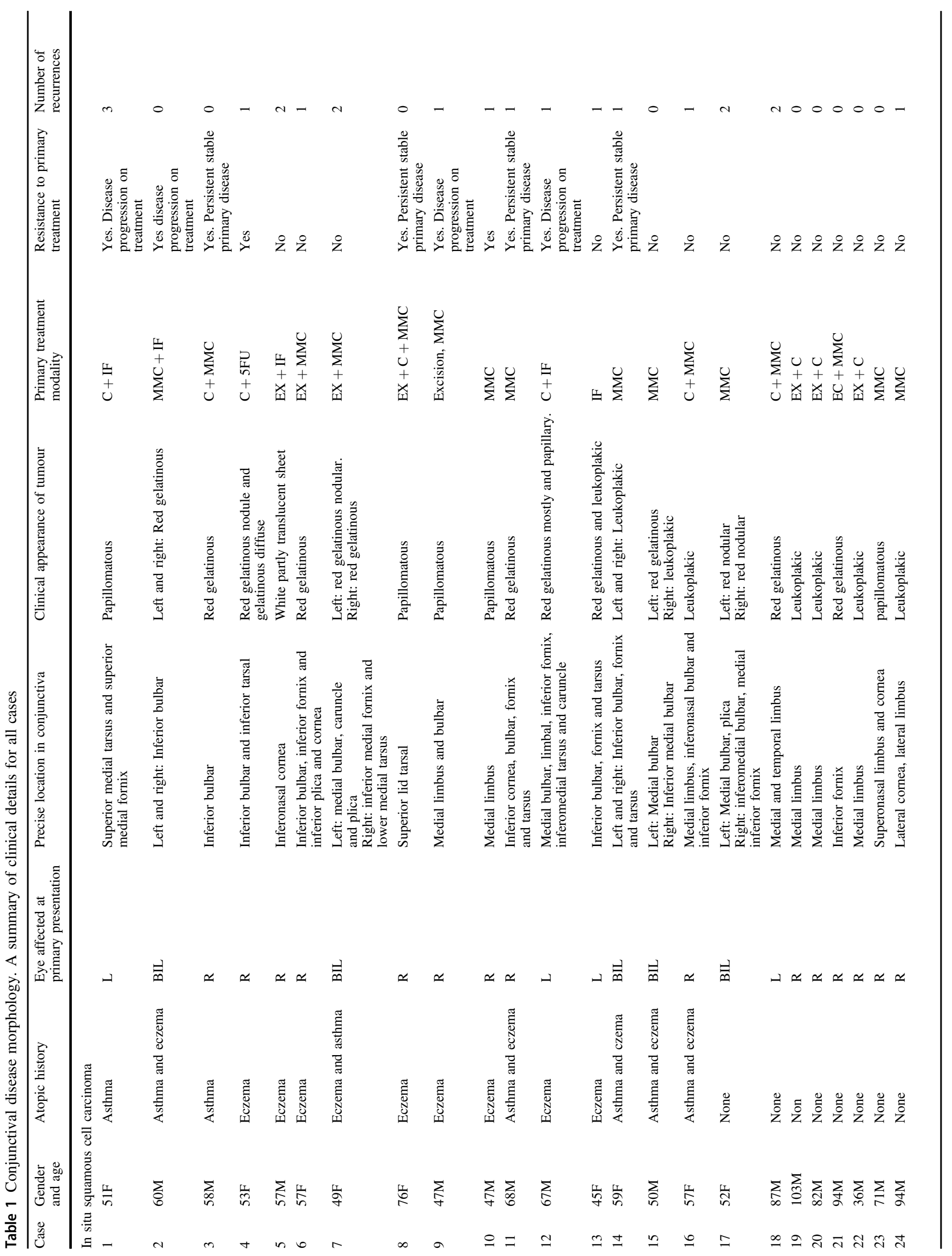




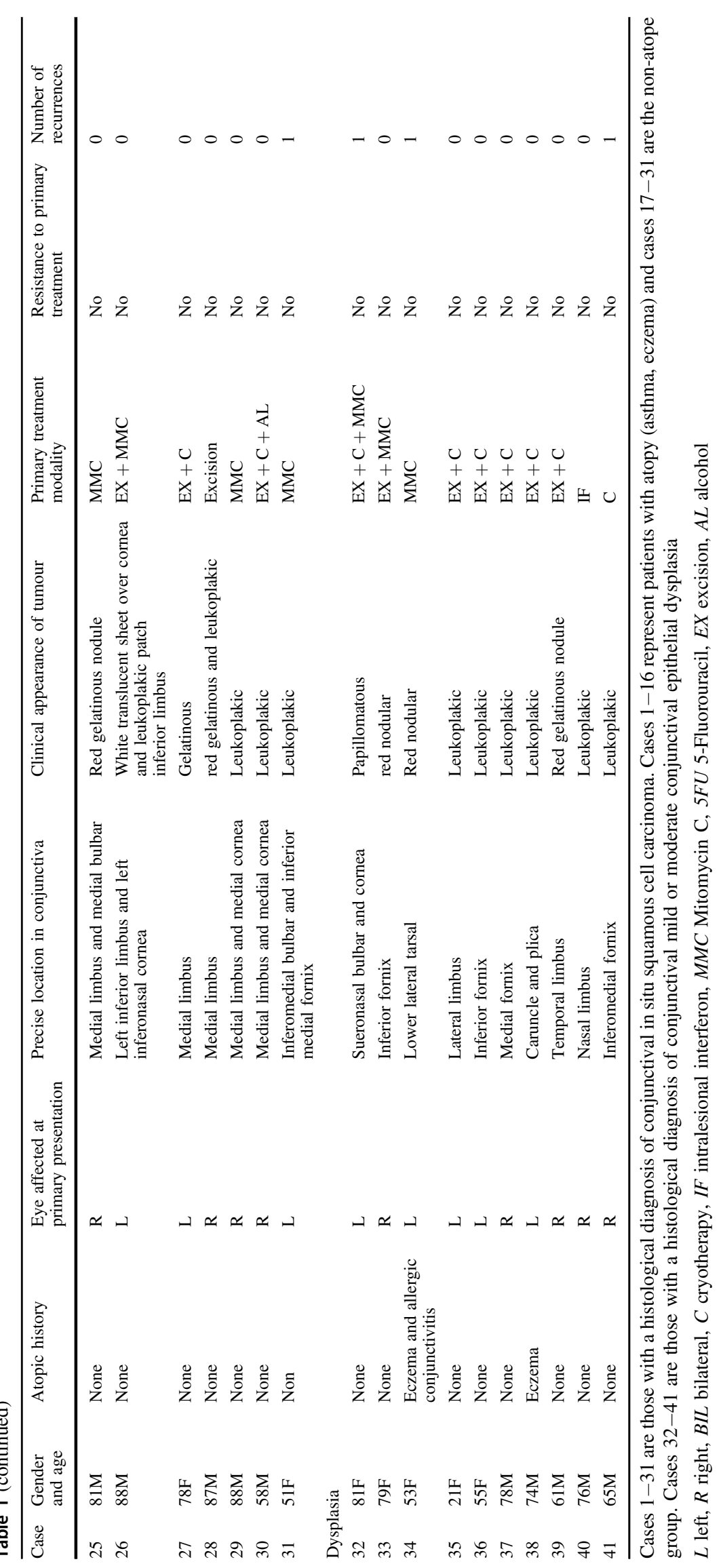




\section{Clinical information}

Relevant patient clinical information was obtained from the clinical records, from the Department of Ophthalmology, Royal Hallamshire Hospital Sheffield. This included the age, sex, side of tumour, the precise conjunctival location, clinical appearance, the primary treatment modality and the recurrence rate and responses to treatment. The presence or absence of atopic conditions (asthma and eczema) was established at the time of the clerking of the patient during their ocular oncology clinic visit, and cross referenced with dermatology and respiratory clinical entries in the hospital clinical notes. These various clinical parameters are summarised in Table 1.

\section{Histopathologic review}

All primary diagnostic histopathology evaluations were based on the haematoxylin and eosin-stained slides. All cases were reported and reviewed by a single ocular pathologist (HSM). The most recent World Health Organisation criteria for grading conjunctival squamous epithelial dysplasia was used in this study [15]. Mild dysplasia is confined to the lower third of the epithelium; moderate dysplasia extends to the middle third of the epithelium; severe dysplasia involves the upper third of the epithelium with retention of surface maturation and in situ squamous carcinoma is full-thickness replacement with dysplastic epithelial cells.

\section{HPV DNA detection and typing}

HPV typing was carried out at two expert diagnostic centres, which we have previously found to produce compatible typing data. Cases 1-30 were analysed at the Scottish HPV Reference Laboratory, Edinburgh, for the presence of HPV DNA. Nucleic acid extraction using the reagents within the DNA mini kit (Qiagen, Hilden, Germany) with a protocol adapted to maximise HPV nucleic acid recovery. DNA extracts were tested for HPV using the Optiplex HPV Genotyping Kit (Diamex GmbH, Heidelberg, Germany). This genotyping test detects $24 \mathrm{HPV}$ types including all established high-risk types $6,11,16,18,26,31,33,35,39$, $42,43,44,45,51,52,53,56,58,59,66,68,70,73$ and 82). For cases 31-41 (15 biopsies), DNA detection was performed at DDL HPV laboratories by PCR amplification with SPF-10 broad-spectrum primers followed by a reverse hybridisation line probe assay, LiPA25 (version 1, Laboratory Biomedical Products, Rijswijk, the Netherlands). LiPA25 enables simultaneous detection of individual 25 high-risk and low-risk HPV types $(6,11,16,18,31$, $33,34,35,39,40,42,43,44,45,51,52,53,54,56,58,59$, $66,68,70$, and 74) [14].

\section{Immunohistochemical/fluorescent staining and image analysis}

The HPV E4 protein was detected using the synthetic single chain antibody TVG405 [16], or the mouse cross-reactive E4 monoclonal antibody FH1.1 [17]. The cellular MCM, p16 ${ }^{\mathrm{INK} 4 \mathrm{a}}$ and TP53 proteins were detected by immunohistochemistry or immunoflourescence on conjunctival biopsies and raft sections using previously described protocols [18]. Alexa-488 labelled TVG405 $(10 \mu \mathrm{g} / \mathrm{ml} \mathrm{IgG})$ was diluted $1 / 150$ prior to use, while FH1.1 $(1 \mathrm{mg} / \mathrm{ml} \mathrm{IgG})$ was diluted 50-fold. Anti-MCM (rabbit monoclonal ab52489, Abcam, Cambridge, UK) was diluted 100-fold, TP53 (mouse monoclonal D01 Santa Cruz Biotechnology, Dallas, Texas, USA) was diluted 1/300. Antibody binding was visualised using anti-mouse or anti-rabbit Alexa Fluor 488or 594-conjugated secondary antibodies (Invitrogen-ThermoFisher) diluted 150-fold. Nuclei were counterstained with DAPI. Immunofluorescence images were scanned using a digital slide scanner (3DHistech, Budapest, Hungary), before the sections were then stained with haematoxylin and eosin and scanned again. P16 $6^{\mathrm{INK} 4 \mathrm{a}}$ immunohistochemistry was performed using the pre-diluted monoclonal mouse anti-human antibody clone E6H4, supplied as part of the CINtec Histology kit (CINtec Ref 9512 Roche). After amplification with a dextran polymer conjugated to HRP, slides were developed using DAB and counterstained with haematoxylin according to the manufacturers' instructions. Sections of cervical high-grade squamous-intraepithelial lesions were used as antibody positive controls. Normal (uninfected) cervical tissue, and HPV-negative organotypic raft material were used as p16 ${ }^{\mathrm{INK4a}}$ negative controls.

\section{Quantification of immunohistochemistry and immunofluorescence data}

P16 ${ }^{\mathrm{INK} 4 \mathrm{a}}$ immunostaining was classified using the convention previously established for the classification of low- and high-grade HPV-associated neoplasia at other epithelial sites [17]. Tissue sections were graded into three groups, depending on whether $\mathrm{p} 16^{\mathrm{INK} 4 \mathrm{a}}$ positivity was (1) absent or focal; (2) diffuse but restricted to the lower third of the epithelium; (3) diffuse in the lower third of the epithelium, but extending also into the upper epithelial layers. Such lesions included those in which the $\mathrm{p} 16^{\mathrm{INK} 4 \mathrm{a}}$ staining occurred throughout the full thickness of the epithelium. MCM scoring was similarly based on approaches used to classify other HPV-associated neoplasia. In this case, grading indicated whether MCM was (1) confined to the basal and parabasal layers only; (2) diffuse but restricted to the lower third of the epithelium; (3) diffuse in the lower third of the epithelium, but extending also into the upper 
epithelial layers, including full thickness. TP53, which is depleted in cells supporting HR HPV gene expression [19], was more difficult to classify using a simple scaling scheme. TP53 staining is described according to its location and extent throughout the thickness of the epithelium.

\section{In situ detection of HPV transcription using RNAscope assay}

In situ hybridisation for HPV16-specific RNA was performed manually using the RNAscope 2.5 assay HPV kit (Advanced Cell Diagnostics Inc., Hayward, CA), with the HPV 16 E6/E7 probe (Cat. Number 311521), according to the manufacturer's instructions. Sections were counterstained with the nuclear stain haematoxylin and were recorded as either positive or negative. Positive cases had prominent granular cytoplasmic and/or nuclear staining when compared with negative control tissue. The integrity of RNA, and the suitability for HPV transcriptional analysis was confirmed in each tissue section using the control probe Pol2A, which detects housekeeping gene expression (Cat. No 310451). An HPV-positive organotypic raft was used as a positive control for the expression of E6/E7 [20] while an HPV-negative organotypic raft was used as a negative control (data not shown).

\section{Results}

\section{Clinical features of conjunctival in situ squamous carcinoma and lower grades of dysplasia}

The study comprised 16/41 (39\%) females and 25/41 (61\%) males (see Table 1). The female age range was $21-87 \mathrm{y}$ and the male age range was $36-103 y$. Of the unilateral eyes affected, there were 12/41 (30\%) left eyes and 24/41 (58\%) right eyes. 5/41 (12\%) bilateral cases were recorded. Cases 1-31 comprised those affected by conjunctival in situ squamous carcinoma and cases $32-41$ by lower grades of dysplasia. In cases 1-31, there were 16 atopes (cases 1-16) and 15 non-atopes (cases 17-31). Of the atopes there were six affected by asthma and eczema, two with asthma alone and eight with eczema alone. Cases 32-41 comprised cases affected by lower grades of squamous dysplasia. Of this group, two were atopic and eight non-atopic.

In cases 1-16 (atope group with in situ squamous carcinoma), there was a strong trend for the medial/ inferomedial bulbar conjunctiva, inferior fornix and inferior tarsal conjunctiva to be affected (14/16 cases) and the clinical appearance of the tumour was red gelatinous or papillomatous (12/16) (see Fig. 1a). In cases 17-31 (non-atope group with in situ squamous carcinoma), the trend was mainly a medial limbal distribution (12/15) and $8 / 15$ had a leukoplakic appearance (see Fig. 1b). In the

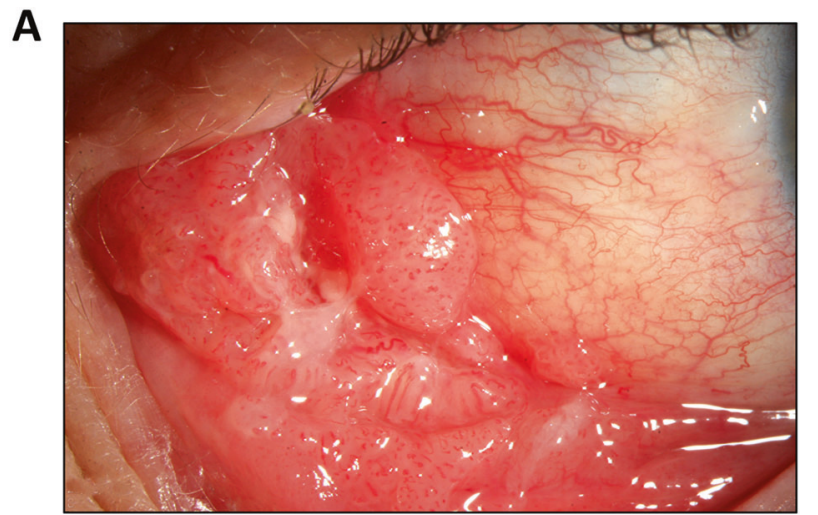

B

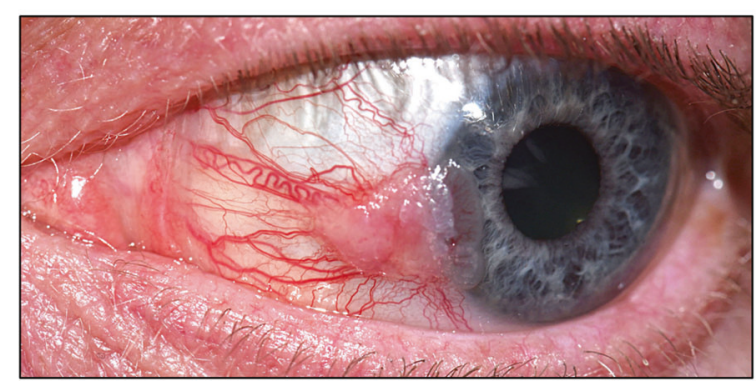

Fig. 1 Conjunctival carcinoma in situ; disease morphology. An example of an HPV DNA-positive lesion arising at the medial bulbar conjunctiva is shown in (a). The full clinical record notes this case as: Left eye: papilleroid, non-leukoplakic, red gelatinous in situ squamous cell carcinoma affecting the medial bulbar conjunctiva, plica, inferior fornix and inferomedial tarsal conjunctiva. An HPV DNA-negative tumour arising at the medial limbal conjunctiva is shown in (b). The full clinical record notes this case as: Left eye: Leukoplakic solitary raised nodule of keratinising in situ squamous cell carcinoma at the medial limbal conjunctiva with medial cornea extension, with tumour feeder vessels. Clinical details of all the tumours examined in this study are listed in Table 1

atope group (cases 1-16), 4/16 had bilateral disease, compared to the non-atope group (cases 17-31) which showed 1/15 bilateral cases. Although HPV testing was not carried out in biopsies from both eyes, the course of disease in each eye was the same. In cases 32-41 (lower grades of dysplasia) there was no particular trend in the location of the tumour, although $6 / 10$ cases had a leukoplakic clinical appearance.

In cases 1-16 (atope group) 10/16 cases showed clinical evidence of resistance to treatment; this comprised either progression of disease during treatment (i.e. increase in size of tumour or new tumour foci appearing) or persistent disease where the size of the tumour was controlled by continuous treatment. In the same group, 12/16 showed evidence of recurrence clinically, which was confirmed by histology. In contrast, within cases 17-31 (non-atope group) there was no resistance to primary treatment and only $4 / 15$ cases recurred. In cases 32-41 (lower grades of dysplasia group), there was no resistance to primary treatment and only $3 / 10$ cases recurred. 


\section{Detection of HPV DNA in conjunctival in situ squamous carcinoma and lower grades of dysplasia}

Biopsies from the 31 cases diagnosed histologically with conjunctival in situ squamous cell carcinoma were further examined in order to investigate the possible involvement of HPV. $13 / 31$ of the cases (42\%) were HPV 16 DNApositive by RT-PCR/line probe assay, while 18 (58\%) were found to be HPV DNA-negative. All 13 HPV DNApositive biopsies contained HPV16 as the only papillomavirus type that was present. Patients with HPV DNApositive in situ squamous carcinoma were all (13/13) found to have an established history of atopy or allergic hypersensitivity, including allergic asthma (2/13) and atopic dermatitis (eczema; (8/13)), with three individuals having a history of both. Of the 18 HPV-negative individuals, only 3 (17\%) had been diagnosed with an atopic condition (see Table 2). Ten cases of conjunctival biopsies that were classified as lower grades of dysplasia following pathology analysis were also examined (see section 'Dysplasia' in Table 2). Only four (out of 10 (40\%)) of these were found to be HPV DNA-positive. HPV type 16 was detected as a single HPV type in $4 / 4$ cases, with HPV 6 (a low-risk HPV type) being found along with HPV 16 in one sample. The remainder of the group (6/10 (60\%)) were HPV DNA-negative. In contrast to the in situ squamous carcinoma group, biopsies taken from the two atopic patients present in this second group were HPV DNA-negative.

\section{Classification of conjunctival in situ squamous carcinoma and lower grades of dysplasia according to gene expression and HPV status}

HR-HPV causality is associated with defined changes in the normal patterns of cellular gene expression within the epithelium, which reflect the molecular processes that become disrupted following virus infection. Most relevant is the loss of TP53, which is mediated by the product of the HR-HPV E6 gene, and the coexpression of cell cycle progression markers such as MCM and Ki67, that are expressed along with $\mathrm{p} 16^{\mathrm{INK} 4 \mathrm{a}}$, a protein which would normally play a role in growth arrest [21]. In HPV-driven high-grade squamousintraepithelial lesions, the cellular MCM, Ki67 and p16 ${ }^{\mathrm{INK} 4 \mathrm{a}}$ proteins are induced by E7, leading to basal and parabasal cell proliferation.

\section{TP53 expression}

The cellular TP53 protein was readily detectable in the basal layers of normal conjunctival epithelium (inset in Fig. 2a), a pattern which resembles our observations in normal cervical tissue. In most of the HPV DNA-positive in situ squamous carcinoma cases, TP53 was undetectable by immunofluorescence microscopy (8/13 (62\%)), as shown for cases 3 and 4 in Fig. 2a. The five remaining HPV DNA-positive cases showed extensive TP53 expression throughout the full thickness of the epithelium (Fig. 2b), a pattern suggesting an absence of HPV E6 gene expression, which is discussed more extensively below. The HPV DNA-negative in situ squamous carcinoma cases were in general more heterogeneous with regard to TP53 expression. The majority (10/ $17(58 \%)$ ) showed clear TP53 expression in the basal epithelial layer, with some lesions sustaining expression into the suprabasal cell layers, as shown for case 14 in Fig. 2c(i). The remainder lacked TP53 expression in both the epithelial basal layer and in the layers above, and in this regard, were broadly similar to the HPV DNA-positive group (Fig. 2c (ii)). Interestingly, of the five HPV DNA-positive in situ squamous carcinoma cases that showed TP53 expression throughout the epithelium, the three that stained positively for $\mathrm{p} 16^{\mathrm{INK} 4 \mathrm{a}}$ were associated with widespread lymphocytic infiltration (case 10 shown in Fig. 2b). It seems likely that the local immune cell environment in these instances is modulating both viral and cellular genes. Indeed, the widespread TP53 and $16^{\mathrm{INK} 4 \mathrm{a}}$ expression seen in case 10 , coupled with the low MCM expression (compare Fig. 2a, b), suggests a lack of significant cell proliferation (senescence) in this lesion at the time point examined, despite the pathology-based diagnosis of in situ squamous carcinoma.

\section{$\mathrm{p} 16^{\mathrm{INK} 4 \mathrm{a}}$ and MCM expression}

In agreement with the above, most of the HPV DNApositive conjunctival in situ squamous carcinomacases (other than case 10; Fig. 2) showed extensive MCM expression throughout the epithelium, which was in contrast to the more limited basal and mid layer staining seen in many of the HPV DNA-negative cases. A similarly robust nuclear and cytoplasmic $\mathrm{p} 16^{\mathrm{INK} 4 \mathrm{a}}$ distribution was also apparent in the majority of the HPV DNA-positive conjunctival in situ squamous carcinomacases (11/13 (85\%), Fig. 2a, b), which is reminiscent of what is seen in cervical high-grade squamous-intraepithelial lesions [17]. Two of the HPV DNA-positive cases (cases 12 and 13) showed only focal, non-basal $\mathrm{p} 16^{\mathrm{INK} 4 \mathrm{a}}$ expression, which is a pattern usually associated with senescence, and in these cases, TP53 levels were also extensive. The combination of low p16 $6^{\mathrm{INK} 4 \mathrm{a}}$ and high TP53 expression was unusual amongst the HPV DNA-positive group, and was distinct from the distribution seen during lymphocytic infiltration (cases 9, 10 and 11), suggesting that cases 12 and 13 may not be caused by HPV, despite being HPV DNA-positive (see below). Amongst the HPV DNA-negative in situ squamous carcinoma group, most were also $\mathrm{p} 16^{\mathrm{INK} 4 \mathrm{a}}$-negative (Table 2), in line with our understanding of $\mathrm{p} 16^{\mathrm{INK} 4 \mathrm{a}}$ function, and the 
Table 2 List of ocular samples. HPV and biomarker expression in conjunctival carcinoma and dysplasia

\begin{tabular}{|c|c|c|c|c|c|c|c|c|c|c|}
\hline Case & $\begin{array}{l}\text { Gender } \\
\text { and age }\end{array}$ & Atopic history & $\begin{array}{l}\text { Conjunctival } \\
\text { pathology }\end{array}$ & $\begin{array}{l}\text { HPV } \\
\text { DNA typing }\end{array}$ & HPV RNA & $\mathrm{P} 16$ & MCM & TP53 & E4 & $\begin{array}{l}\text { Lymphocytic } \\
\text { infiltration }\end{array}$ \\
\hline \multicolumn{11}{|c|}{ In situ squamous cell carcinoma } \\
\hline 1 & $51 \mathrm{~F}$ & Asthma & In situ SCC & HPV 16 & + & 3 & 3 & -ve (basal) & & \\
\hline 2 & $60 \mathrm{M}$ & $\begin{array}{l}\text { Asthma } \\
\text { and eczema }\end{array}$ & In situ SCC & HPV 16 & + & 3 & 3 & -ve (basal) & & \\
\hline 3 & $58 \mathrm{M}$ & Asthma & In situ SCC & HPV 16 & + & 3 & 3 & -ve (basal) & & \\
\hline 4 & $53 \mathrm{~F}$ & Eczema & In situ SCC & HPV 16 & + & 3 & 3 & -ve (basal) & & \\
\hline 5 & $57 \mathrm{M}$ & Eczema & In situ SCC & HPV 16 & + & 3 & 1 & -ve (basal) & & \\
\hline 6 & $57 \mathrm{~F}$ & Eczema & In situ SCC & HPV 16 & + & 3 & 3 & -ve (basal) & & \\
\hline 7 & $49 \mathrm{~F}$ & $\begin{array}{l}\text { Asthma } \\
\text { and eczema }\end{array}$ & In situ SCC & HPV16 & + & 3 & 3 & -ve (basal) & & \\
\hline 8 & $76 \mathrm{~F}$ & Eczema & In situ SCC & HPV 16 & + & 3 & 3 & -ve (basal) & $\checkmark$ & \\
\hline 9 & $47 \mathrm{M}$ & Eczema & In situ SCC & HPV 16 & + & 3 & 3 & + ve (throughout) & & $\checkmark$ \\
\hline 10 & $47 \mathrm{M}$ & Eczema & In situ SCC & HPV 16 & + & 3 & 3 (weak) & + ve (throughout) & & $\checkmark$ \\
\hline 11 & $68 \mathrm{M}$ & $\begin{array}{l}\text { Asthma } \\
\text { and eczema }\end{array}$ & In situ SCC & HPV 16 & + & 3 & 3 & + ve (throughout) & & $\checkmark$ \\
\hline 12 & $67 \mathrm{M}$ & Eczema & In situ SCC & HPV 16 & - & 1 & 3 & +ve (throughout) & & \\
\hline 13 & $45 \mathrm{~F}$ & Eczema & In situ SCC & HPV 16 & - & 1 & 3 & + ve (throughout) & & \\
\hline 14 & $59 \mathrm{~F}$ & $\begin{array}{l}\text { Asthma } \\
\text { and eczema }\end{array}$ & In situ SCC & Negative & - & 1 & 1 & + ve (throughout) & & \\
\hline 15 & $50 \mathrm{M}$ & $\begin{array}{l}\text { Asthma } \\
\text { and eczema }\end{array}$ & In situ SCC & Negative & ND & 1 & 1 & +ve (throughout) & & \\
\hline 16 & $57 \mathrm{~F}$ & $\begin{array}{l}\text { Asthma } \\
\text { and eczema }\end{array}$ & In situ SCC & Negative & - & 1 & 2 & -ve (basal) & & \\
\hline 17 & $52 \mathrm{~F}$ & None & In situ SCC & Negative & ND & 1 & 3 & +ve (throughout) & & $\checkmark$ \\
\hline 18 & $87 \mathrm{M}$ & None & In situ SCC & Negative & ND & 1 & 1 & -ve (throughout) & & \\
\hline 19 & $103 \mathrm{M}$ & None & In situ SCC & Negative & ND & 1 & 1 & -ve (throughout) & & \\
\hline 20 & $82 \mathrm{M}$ & None & In situ SCC & Negative & ND & 1 & 3 & $\begin{array}{l}+\mathrm{ve} \\
\text { (throughout) (weak) }\end{array}$ & & $\checkmark$ \\
\hline 21 & $94 \mathrm{M}$ & None & In situ SCC & Negative & ND & 1 & 1 & -ve (throughout) & & \\
\hline 22 & $36 \mathrm{M}$ & None & In situ SCC & Negative & ND & 1 & 1 & -ve (throughout) & & \\
\hline 23 & $71 \mathrm{M}$ & None & In situ SCC & Negative & ND & 1 & 3 & -ve (basal) & & \\
\hline 24 & $94 \mathrm{M}$ & None & In situ SCC & Negative & ND & 1 & 1 & +ve (basal) & & \\
\hline 25 & $81 \mathrm{M}$ & None & In situ SCC & Negative & - & 3 & 3 & + ve (throughout) & & $\checkmark$ \\
\hline 26 & $88 \mathrm{M}$ & None & In situ SCC & Negative & - & 2 & 3 & +ve (basal—weak) & & \\
\hline 27 & $78 \mathrm{~F}$ & None & In situ SCC & Negative & ND & 1 & 1 & + ve (basal) & & \\
\hline 28 & $87 \mathrm{M}$ & None & In situ SCC & Negative & ND & 1 & 3 & + ve (basal) & & \\
\hline 29 & $88 \mathrm{M}$ & None & In situ SCC & Negative & ND & 1 & 3 & - ve (throughout) & & \\
\hline 30 & $58 \mathrm{M}$ & None & In situ SCC & Negative & $\mathrm{ND}$ & 1 & 3 & Patchy & & \\
\hline 31 & $51 \mathrm{~F}$ & None & In situ SCC & Negative & $\begin{array}{l}- \text { (RNA } \\
\text { degraded) }\end{array}$ & 3 & 2 & -ve (basal) & & \\
\hline \multicolumn{11}{|c|}{ Dysplasia } \\
\hline 32 & $81 \mathrm{~F}$ & None & $\begin{array}{l}\text { Moderate } \\
\text { dysplasia }\end{array}$ & Negative & - & 1 & 2 & + ve (basal) & & \\
\hline 33 & $79 \mathrm{~F}$ & None & $\begin{array}{l}\text { Mild and } \\
\text { moderate } \\
\text { dysplasia }\end{array}$ & Negative & - & 1 & 2 & + ve (basal) & & \\
\hline 34 & $53 \mathrm{~F}$ & $\begin{array}{l}\text { Eczema and } \\
\text { allergic } \\
\text { conjunctivitis }\end{array}$ & $\begin{array}{l}\text { Mild and } \\
\text { moderate } \\
\text { dysplasia }\end{array}$ & Negative & - & 1 & 2 & $+\mathrm{ve}$ (basal) & & \\
\hline
\end{tabular}


Table 2 (continued)

\begin{tabular}{|c|c|c|c|c|c|c|c|c|c|c|}
\hline Case & $\begin{array}{l}\text { Gender } \\
\text { and age }\end{array}$ & Atopic history & $\begin{array}{l}\text { Conjunctival } \\
\text { pathology }\end{array}$ & $\begin{array}{l}\text { HPV } \\
\text { DNA typing }\end{array}$ & HPV RNA & P16 & MCM & TP53 & $\mathrm{E} 4$ & $\begin{array}{l}\text { Lymphocytic } \\
\text { infiltration }\end{array}$ \\
\hline 35 & $21 \mathrm{~F}$ & None & $\begin{array}{l}\text { Moderate } \\
\text { dysplasia }\end{array}$ & Negative & - & 1 & 2 & + ve (basal) & & \\
\hline 36 & $55 \mathrm{~F}$ & None & $\begin{array}{l}\text { Mild and } \\
\text { moderate } \\
\text { dysplasia }\end{array}$ & HPV 16 & - & 1 & 2 & + ve (basal) & & \\
\hline 37 & $78 \mathrm{M}$ & None & $\begin{array}{l}\text { Moderate } \\
\text { dysplasia }\end{array}$ & HPV 16 & - & 1 & 2 & + ve (basal) & & \\
\hline 38 & $74 \mathrm{M}$ & Eczema & Mild dysplasia & Negative & - & 1 & 2 & + basal & & \\
\hline 39 & $61 \mathrm{M}$ & None & $\begin{array}{l}\text { Moderate } \\
\text { dysplasia }\end{array}$ & HPV 16 & - & 1 & 2 & + ve (throughout) & & \\
\hline 40 & $76 \mathrm{M}$ & None & $\begin{array}{l}\text { Moderate } \\
\text { dysplasia }\end{array}$ & Negative & - & 1 & 2 & +ve (throughout) & & \\
\hline 41 & $65 \mathrm{M}$ & None & $\begin{array}{l}\text { Squamous } \\
\text { metaplasia }\end{array}$ & HPV 16, 6 & - & 1 & 2 & + ve (basal) & & \\
\hline
\end{tabular}

HPV DNA and RNA analysis of the conjunctival in situ squamous carcinoma and dysplasias examined in this study, along with biomarker and histological phenotype. HPV DNA-positive cases are highlighted in bold

role of 'deregulated E7 expression' in stimulating this protein during HPV carcinogenesis. A correlation between p16 ${ }^{\mathrm{INK} 4 \mathrm{a}}$ expression and HPV DNA-positivity was not apparent in the mild and moderate dysplastic conjunctival lesions, which might suggest HPV DNA presence, rather than any overt causal association. Of the four HPV 16 DNA-positive cases, one (case 41) was a squamous metaplasia, and contained only discrete $\mathrm{p} 16^{\mathrm{INK} 4 \mathrm{a}}$-positive cells. This is also observed during cervical metaplasia, and was classified as 'p16 ${ }^{\mathrm{INK} 4 \mathrm{a}}$-negative' in line with published criteria [22]. The remaining three HPV DNA-positive cases of conjunctival dysplasia (cases 36, 37, and 39) were MCMpositive in the lower half of the epithelium, and TP53positive in basal cells or throughout the epithelium, an ambiguous pattern that does not support HPV causality. While there is a broadly similar pattern of biomarker expression in HPV-driven conjunctival in situ squamous carcinoma, the lower-grades of conjunctival dysplasia group is heterogeneous, a situation which may reflect their diverse origins.

\section{Markers of the productive HPV life cycle}

In contrast to $\mathrm{MCM}$ and $\mathrm{p} 16^{\mathrm{INK} 4 \mathrm{a}}$, markers that allow visualisation of the productive stages of the HPV life cycle are usually expressed in a limited number of surfaceproximal epithelial cells in high-grade lesions (e.g. cervical high-grade squamous-intraepithelial lesions). In cervical low-grade squamous-intraepithelial lesions E4 is very highly expressed and coincides with the onset of viral genome amplification [17]. As expected, the majority of the HPV DNA-positive conjunctival in situ squamous carcinoma cases were HPV E4-negative. One case was found with a characteristic pattern of E4 in a small number of cells close to the epithelial surface (see Fig. 3a, c). Curiously, E4 expression was not seen in the four conjunctival dysplasia cases, suggesting that like the oropharynx and the endocervix, the conjunctiva may not be an epithelial site where productive HPV infection is supported. In fact, the absence of E4 in these low-grade lesions, when considered alongside the presence of TP53, and the absence of $\mathrm{p} 16^{\mathrm{INK} 4 \mathrm{a}}$, prompts re-interpretation of the HPV DNA-positive result in these lesions.

\section{Detection of HPV transcription in conjunctival in situ squamous carcinoma and dysplasias}

The detection of HPV DNA in cases showing biomarker patterns pathognomonic of viral neoplasia leads us to suspect a causal association between HPV infection and the development of a subset of conjunctival in situ squamous carcinoma. Cellular biomarkers such as those used in this study can however be deregulated in situations other than HPV infection, prompting us to look more directly at the contribution of HPV16 E6 and E7. Unlike the HPV E4 protein, which is abundantly expressed during productive infection, the E6 and E7 gene products are expressed at only low levels, and are not routinely detected using immunostaining approaches. To overcome this, the 13 carcinoma in situ samples that were HPV 16 DNA-positive by whole tissue sectionPCR, as well as all the conjunctival lower grades of dysplasia biopsies and four of the HPV DNA-negative in situ squamous carcinoma cases, were screened for viral gene expression using an RNAscope in situ methodology. Sections were also screened using the cellular Pol2A 

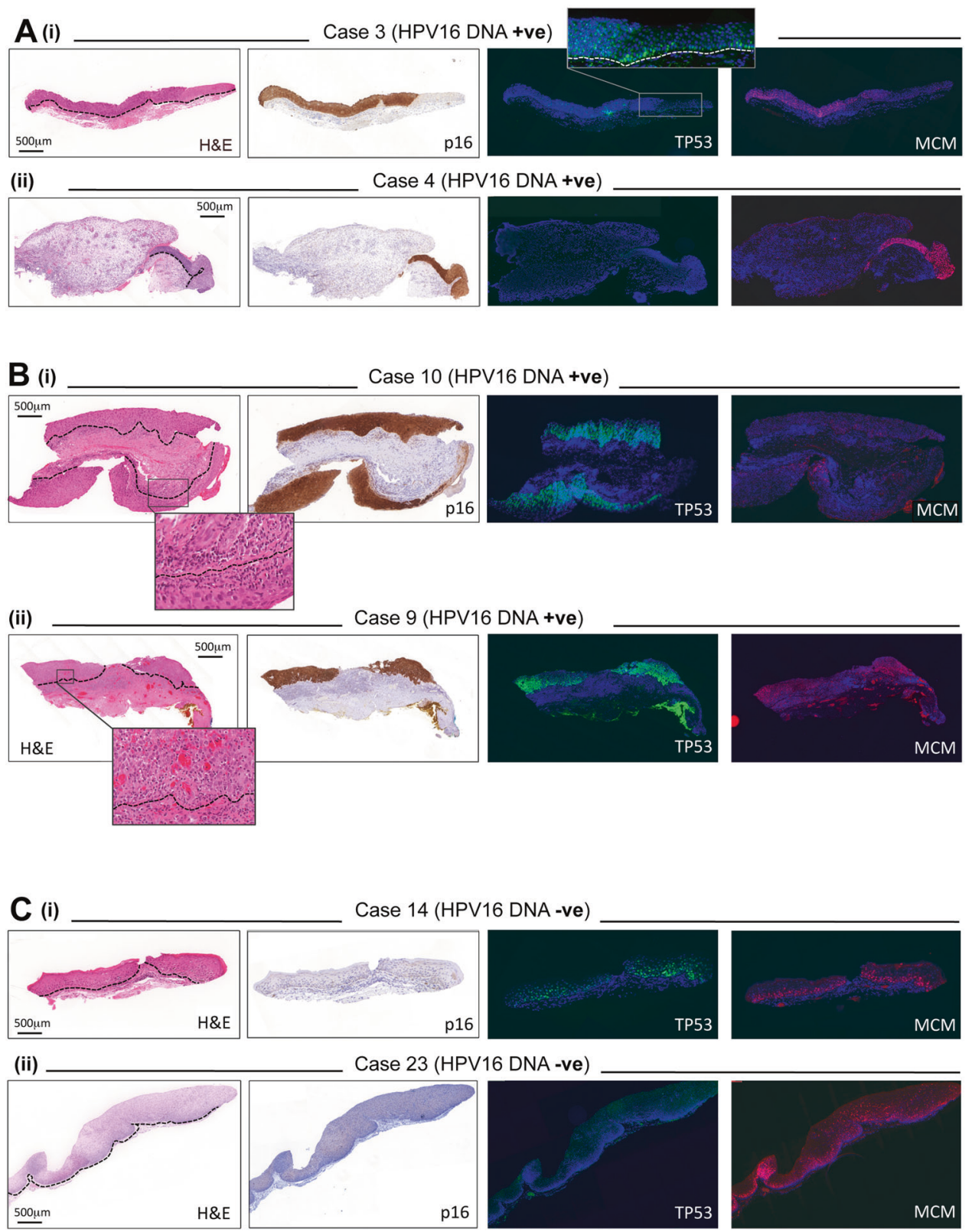

Fig. 2 Differences in biomarker expression in HPV DNA-positive and -negative conjunctival in situ squamous carcinoma. a Conjunctival in situ squamous carcinomas positive for HPV DNA were subject to conventional H\&E staining (left panel), or were stained for $\mathrm{p} 16^{\mathrm{INK} 4 \mathrm{a}}$ by immunohistochemistry (brown), or for TP53 (green) or MCM (red) using an immunofluorescence approach (IF (rightmost panels)). Nuclei are counterstained using DAPI in the IF images. The majority of HPV DNA-positive conjunctival in situ squamous carcinomacases were p16 ${ }^{\mathrm{INK} 4 \mathrm{a}}$-positive, TP53-negative and MCM-positive. A junctional region is present in case 3 , which is marked by an abrupt $\mathrm{p} 16^{\mathrm{INK} 4 \mathrm{a}}$ boundary. TP53 was absent in the lesional area, but was present in the

housekeeping gene probe, in order to identify any that may have generally poor RNA integrity, and thus be unsuitable for such analysis. All the sections showed evidence of housekeeping gene expression throughout the epithelial layers (although case 31 showed some adjacent 'normal' epithelium (inset). b Examples of HPV DNApositive, p16 ${ }^{\mathrm{INK} 4 \mathrm{a}}$-positive cases that were also TP53-positive, but MCM-negative were also observed. In these cases, widespread lymphocytic infiltration was apparent as shown in the H\&E enlargement inset. c Conjunctival in situ squamous carcinoma cases negative for HPV DNA, are typically negative for $\mathrm{p} 16^{\mathrm{INK4a}}$, and variably positive for TP53 and MCM. In $\mathbf{a}, \mathbf{b}$ and $\mathbf{c}$, different cases are shown in panels (i) and (ii). Details of the cases shown in $(\mathbf{a}-\mathbf{c})$ are outlined in Table 1. The position of the epithelial basal lamina is shown in the left most images as a dotted line

degradation in early sections), indicative of intact RNA, and in these cases, the extent of HPV16 E6/E7 gene expression was subsequently assessed. In order to substantially improve the signal-to-noise ratio of RNA ISH, RNAscope employs a probe design strategy much akin 

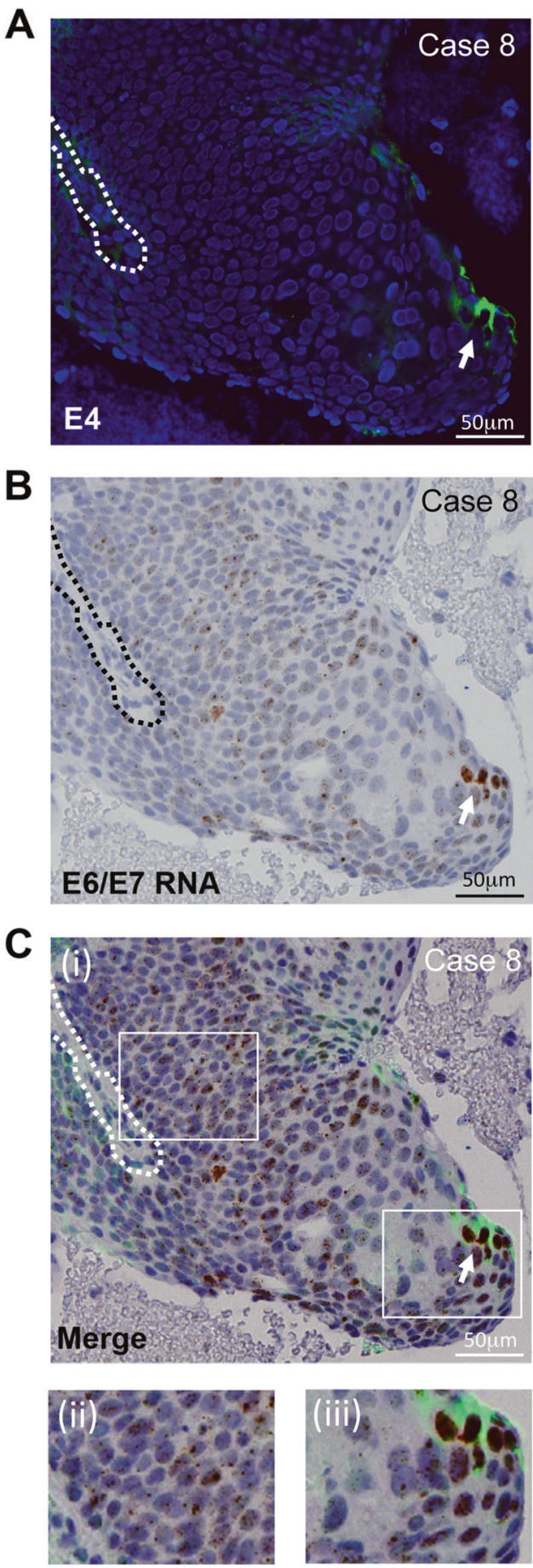

to fluorescence resonance energy transfer (FRET), in which two independent probes (double $\mathrm{Z}$ probes) have to hybridise to the target sequence in tandem in order for signal amplification to occur. As it is highly unlikely that two independent probes will hybridise to a non-specific target right next to each other, this design concept ensures selective amplification of target-specific signals. For each target RNA species, $\sim 20$ double $\mathrm{Z}$ target probe pairs are designed to specifically hybridise to the target molecule,
Fig. 3 Expression of HPV E4 protein can occur in conjunctival HPV infections. a One conjunctival in situ squamous carcinoma case (case 8) showed sporadic expression of the HPV E4 protein (green (arrowed)), which could be visualised by IF in cells close to the epithelial surface. The cell nuclei were counterstained with DAPI. b HPV E6/E7 expression was apparent in this lesion following RNA scope analysis, with an elevation of expression in sporadic cells close to the epithelial surface (arrowed). c (i) Cells showing elevated E6/E7 expression, also expressed E4 in this lesion (arrowed), which indicates that progression through the papillomavirus life cycle is occurring in these cells. The difference in the intensity of signal between the basal/ parabasal (ii) and suprabasal/superficial (iii) cell layers is shown at the bottom of the figure in the enlargement panels. The position of the basal lamina is shown as a dotted line

but not to non-targeted molecules. Each target $\mathrm{Z}$ probe contains three elements: The lower region of the $\mathrm{Z}$ is an 18- to 25-base region that is complementary to the target RNA. This sequence is selected for target-specific hybridisation and uniform hybridisation properties. A spacer sequence links the two components of the probe. The upper region of the $\mathrm{Z}$ is a 14-base tail sequence. The two tails from a double $\mathrm{Z}$ probe pair forms a 28-base binding site for the pre-amplifier. The HPV 16 E6/E7 probe recognises sequences between bases 84 in E6 and 753 of E7. Although this region extends beyond nucleotide 670, transcripts originating from the late promoter (P670) are not detected, as only a single $\mathrm{ZZ}$ pair is contained within this region ( $\geq 3 \mathrm{ZZ}$ pairs (i.e. $150 \mathrm{bp}$ ) required for RNAscope signal (https://acdbio.com)). Initial staining was carried out with chromogenic development on case 8 (Fig. 3b), which was HPV DNApositive, had a pathognomonic biomarker expression pattern, and contained several small areas where viral E4 expression was found. As expected, this lesion showed extensive HPV16 E6/E7 expression throughout the epithelium, with a clear elevation in E6/E7 abundance in regions of E4 positivity (Fig. 3c), which fits well with the established life cycle role of E6, E7 and E4 in HPV genome amplification. Indeed, a similar but more dramatic upregulation of viral gene expression is typical of productive HPV16 infections, as seen following reconstruction of the HPV16 life cycle in organotypic raft culture (Fig. 4a). Basal and suprabasal E6/E7 expression, often with some degree of E6/E7 elevation towards the epithelial surface, was clearly evident in $11 / 13$ (85\%) of the conjunctival in situ squamous carcinomacases that were HPV 16 DNA-positive (Table 2, Fig. 4b, c). The two HPV DNA-positive cases that failed to show an E6/ E7 RNAscope signal also failed to show the classical biomarker pattern typically associated with HPV-induced neoplasia, and most notably were not associated with elevated $\mathrm{p} 16^{\mathrm{INK} 4 \mathrm{a}}$ expression (see Table 2 ). In these cases, we suspect that HPV DNA is present either as a subclinical infection adjacent to the in situ squamous 

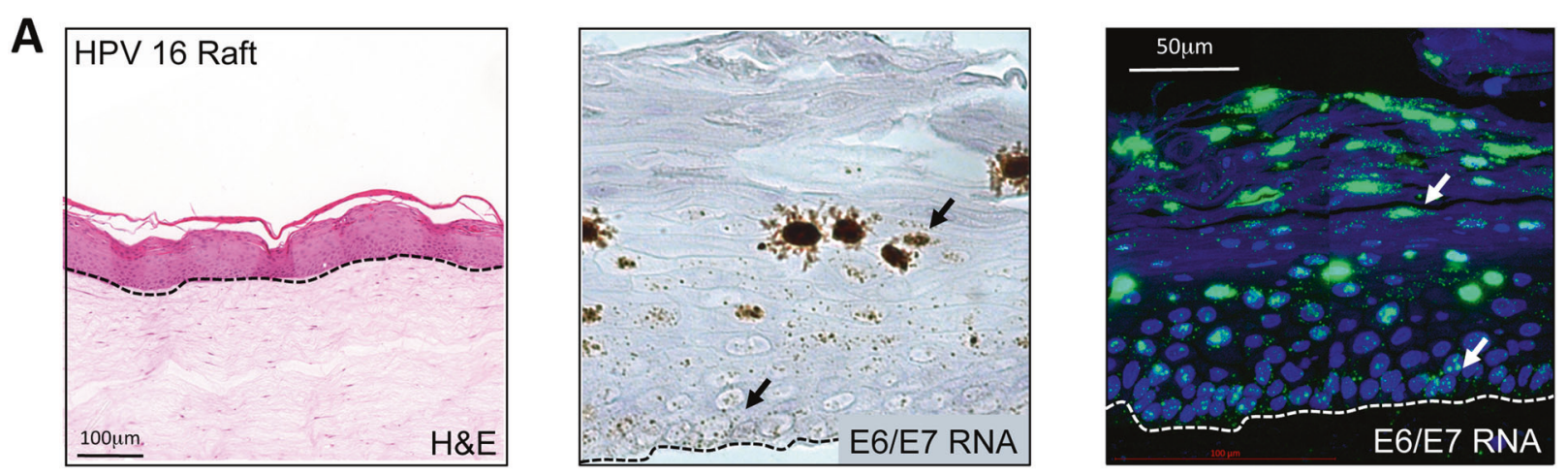

B
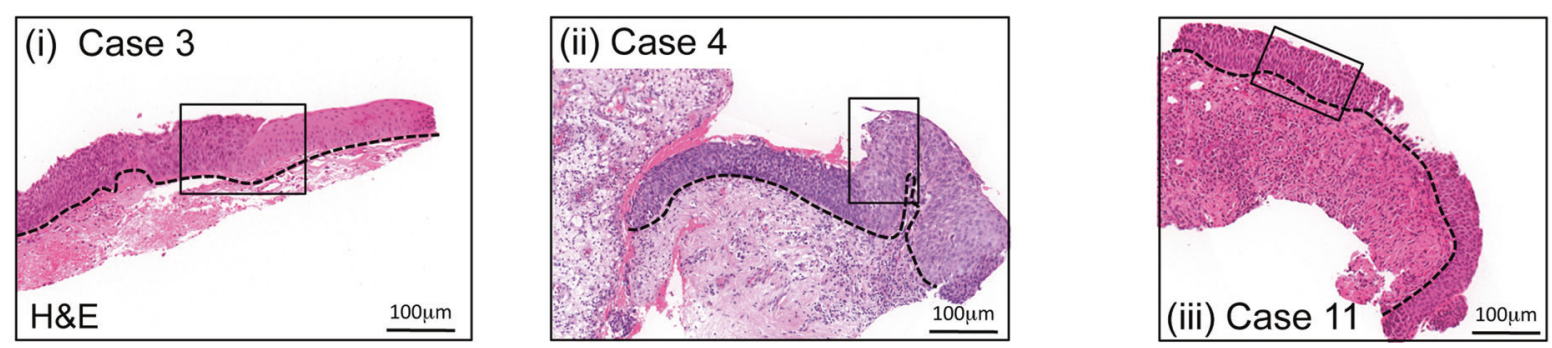

C
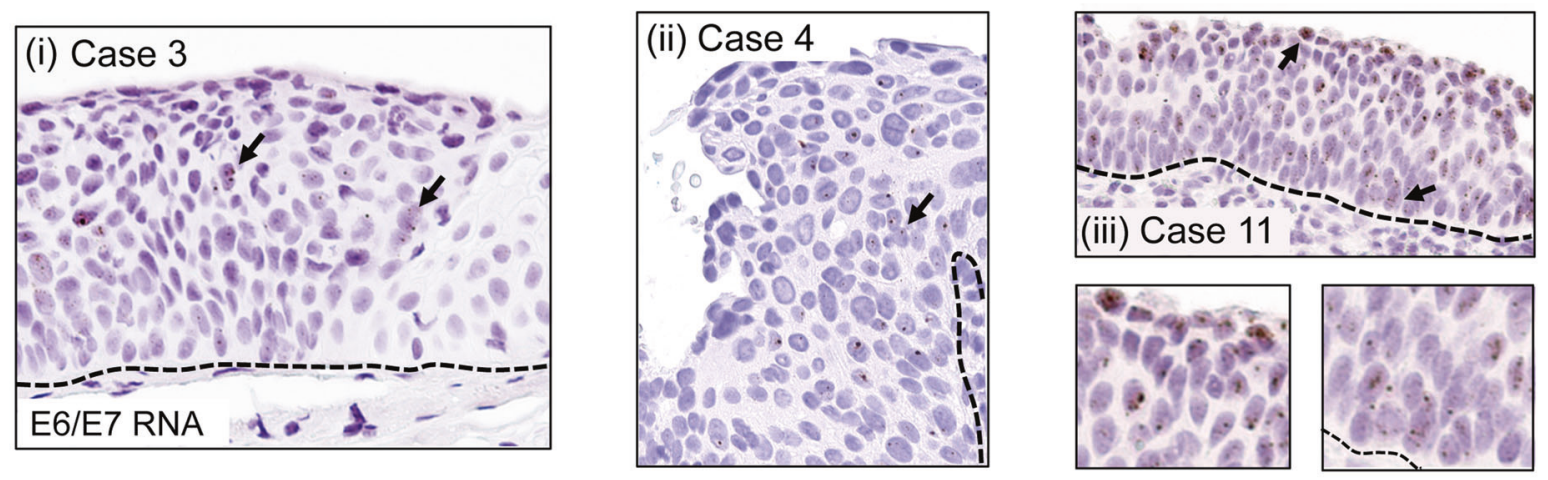

D
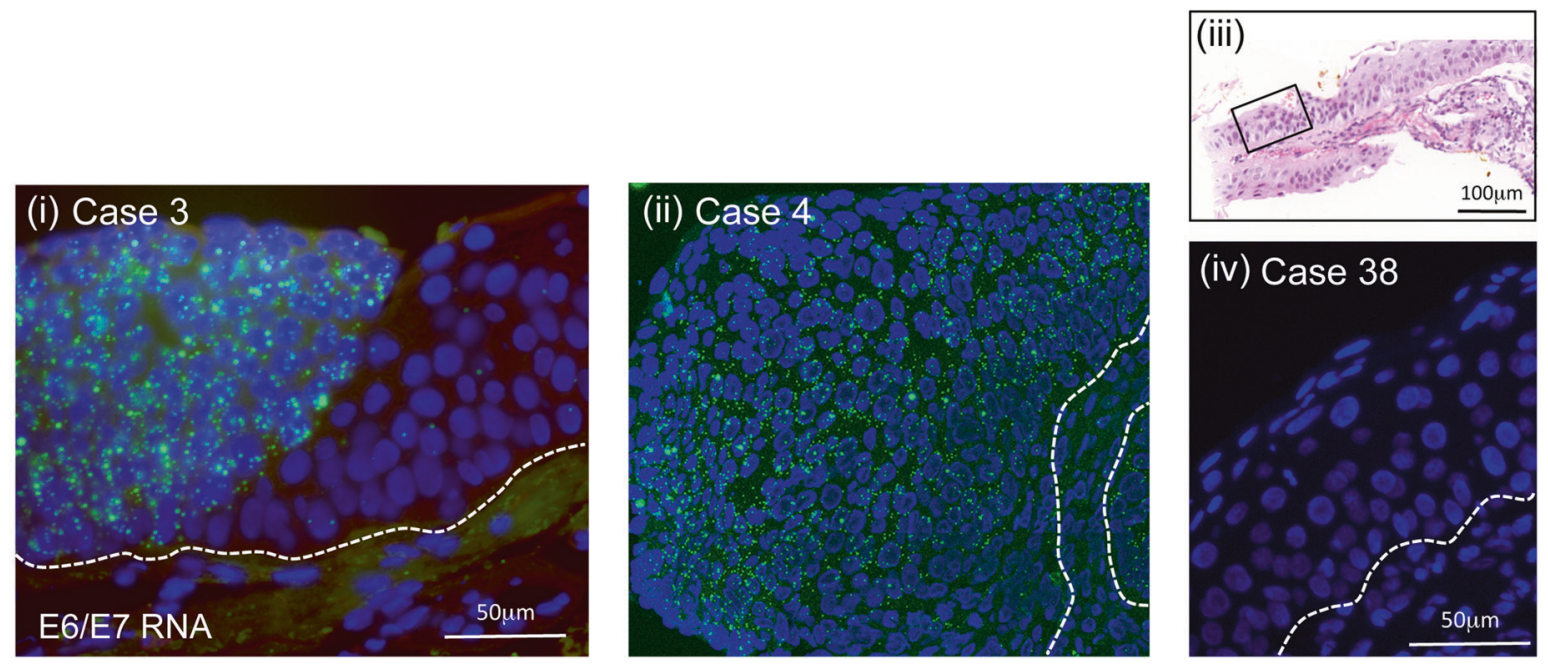

carcinoma tissue, or that HPV DNA or HPV virions are present in the sample in the absence of an active infection.
Because high-grade cervical neoplasia can arise from productive low-grade neoplasia, the lower grades of dysplasia biopsies were also examined in the same way. In this 
Fig. $4 \mathrm{HPV}$ transcription in conjunctival in situ squamous carcinoma is characteristic of abortive infection. a The productive HPV life cycle can be supported in organotypic raft culture of HPV-infected epithelial cells. HPV16 raft organisation is shown in the left most panel, with the 'basal lamina' marked by a dotted line. E6/E7 transcripts were detected in adjacent sections using immunohistochemistry (brown; centre panel), or immunoflourescence (green; right panel) methodology. The upper arrow in both panels indicates the elevation in expression that accompanies viral genome amplification in the mid epithelial layers, which persists towards the epithelial surface depending on the extent of epithelial terminal differentiation. The lower arrow shows that E6/E7 gene expression occurs in the basal and parabasal cell layers during productive infection. b H\&E staining of three of the conjunctival in situ squamous carcinomacases to show the regions that are enlarged in the E6/E7 RNAscope stains illustrated in (c). c Detection of HPV E6/E7 transcription is revealed by the presence of brown spots in the cytoplasm and nucleus (arrowed in (i)-(iii)). In $\mathbf{b}$, $\mathbf{c}$ and $\mathbf{d}$, different cases are shown in panels (i), (ii) (iii) and (iv). Case 3, shown in (i), includes a junction between infected epithelium and normal epithelium. Some elevation in E6/E7 expression towards the epithelial surface is apparent in case 3, but is more obvious in case 11 (iii). An enlargement of the surface epithelial layers and the basal/parabasal layers is shown in the lower boxes in (iii). d Immunofluorescent detection of the E6/E7 RNAscope signal shows viral gene expression more conclusively. The junction between infected and normal epithelium is apparent in Case 3 (i). Uniform E6/E7 expression throughout the epithelial layers is apparent in case 4 (ii). No E6/E7 expression was apparent in any of the conjunctival dysplasias, with the results shown for Case 38 shown in (iii)

case, none of the four HPV DNA-positive biopsies showed evidence of viral gene expression using the in situ RNAscope approach (Table 2), as did none of the HPV DNAnegative in situ squamous carcinoma cases. In carrying out these studies, we noted that tyramide development followed by fluorescence visualisation of the RNAscope signal offered a significant sensitivity increase (see Fig. 4a centre and rightmost panels), particularly when visualising viral gene expression in the carcinoma cases (Fig. 4d), as can be seen when the images shown in Fig. $4 \mathrm{c}$ are compared with those shown in Fig. 4d. Although several attempts were made to show evidence of HPV gene expression amongst the HPV DNA-positive dysplasia, we were unable, even using this fluorescence approach, to generate any convincing E6/E7 signals in these lesions (see Fig. 4d (iii)). We assume that the levels of viral gene expression are either at the limits of sensitivity using this approach, or more likely, that the conjunctival dysplasia examined here, are not causally associated with HPV. The absence of $16^{\mathrm{INK} 4 \mathrm{a}}$ expression in these dysplastic lesions is compatible with this assumption. Interestingly, we were not able to detect HPV DNA in these biopsies using an in situ hybridisation approach, despite being able to localise HPV16 genomes to the nuclei of infected cells in the conjunctival in situ squamous carcinomacases (Fig. 5). In these lesions, the distribution of HPV DNA-positive cells was similar to that observed using the RNAscope approach (Fig. 5a), with the diffuse nuclear pattern suggesting the presence of episomal HPV genomes. As with the RNAscope result, an elevated signal was apparent in some cells close to the epithelial surface, which fits well with the modest amplification of viral genomes expected in these lesions.

\section{Discussion}

Although several studies have suggested that conjunctival in situ squamous carcinoma may have an association with HPV, most reports have been restricted to the detection of HPV DNA by PCR analysis, and have not yet confirmed active viral infection or HPV causality. Indeed, HPV DNA may be present either as a passenger virus or as a subclinical infection in adjacent normal tissue, which can lead to a positive result in a tumour biopsy. The detection of HPV in urine samples, which is sometimes used as an indication of the presence of cervical neoplasia [23], is a clear example that illustrates the sensitivity of HPV DNA detection methods, and the caution required in interpreting a positive result. To prove causality, the presence of viral mRNA or viral proteins, and a demonstration of their phenotypic consequences at the site of infection is required-with infection-biomarkers allowing visualisation of the cellular changes that may eventually contribute to the tumourogenic state. In this study we have combined DNA typing, with classical immunohistochemistry to detect viral proteins and surrogate markers of virus infection. In the majority of the conjunctival in situ squamous carcinomas examined here, such markers were closely associated with active HPV E6/ E7 transcription, and with the well-established pathognomonic changes that are typically associated with the development of HPV-driven cancer.

The primary aim of our study was to examine the causal association between high-risk HPV and conjunctival in situ squamous carcinoma, rather than to provide information on the incidence of the disease. Only one high-risk HPV type was detected amongst our collection of conjunctival biopsies. The limited HPV diversity seen in the conjunctival in situ squamous carcinoma cases has some parallels with what has been reported at the oropharynx and endocervix, where HPV16, and only a small number of other HPV types cause the vast majority of the cancers. As no single biomarker can be used to establish HPV causality, we performed a combination of biomarker stains to help confirm HPV involvement. In most of the HPV DNA-positive conjunctival in situ squamous carcinomas, immunohistochemistry revealed extensive $\mathrm{p} 16^{\mathrm{INK} 4 \mathrm{a}}$ and $\mathrm{MCM}$ expression, along with an absence of TP53 in the epithelial basal layer. The HPV E4 protein was not detected in the majority of biopsies examined, similar to what is seen in cervical high-grade squamous-intraepithelial lesions, where the virus is undergoing an abortive rather than a productive life cycle. Only in one of the conjunctival in situ squamous carcinoma cases was expression of the HPV E4 
A

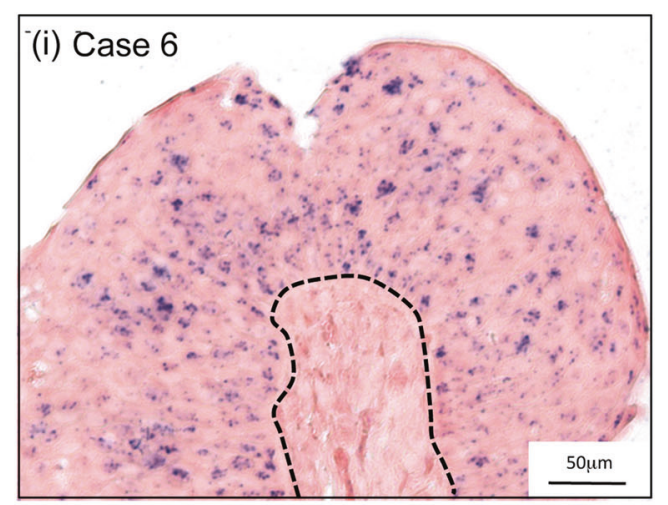

B

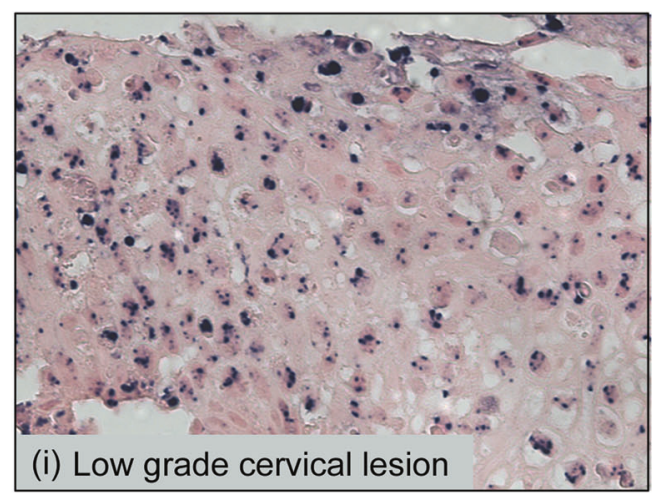

Fig. 5 Detection of HPV DNA by in situ hybridisation. a HPV DNA is apparent in lesions showing evidence of HPV transcriptional activity in the E6/E7 RNAscope analysis shown in Fig. 3 (case 6 (i) and case 3 (ii) shown). Signal intensity was either uniform across the full thickness of the epithelium (i), or showing some evidence of increase in

protein detected in a limited number of cells towards the epithelial surface. HPV activity within the conjunctival in situ squamous carcinoma tissue was further confirmed by HPV transcriptional analysis using an RNA in situ staining approach (RNAScope-ACD, Newark, California). In support of the above, HPV16 E6/E7 transcripts were apparent throughout the neoplastic epithelium, and stopped abruptly at the boundary with the normal uninfected epithelium (Fig. 4). In the one conjunctival in situ squamous carcinoma case that was HPV E4-positive, E4 expression was restricted to a few cells close to the epithelial surface that showed extensive HPV E6/E7 viral gene expression, compatible with limited initiation of the late phase of the papillomavirus life cycle. Apart from this case, only a very limited increase in HPV E6/E7 transcription (and viral DNA abundance) was seen in the upper epithelial layers, when compared to HPV16 DNA-positive organotypic rafts, supporting the conclusion that conjunctival epithelium is primarily a site of abortive rather than productive HPV16 infection. The rise in E6/E7 RNAscope spot density close to the epithelial surface in some lesions (Fig. 4) may reflect the different dynamics of cells at the conjunctival surface, although this is also seen sometimes in cervical highgrade squamous-intraepithelial lesions.
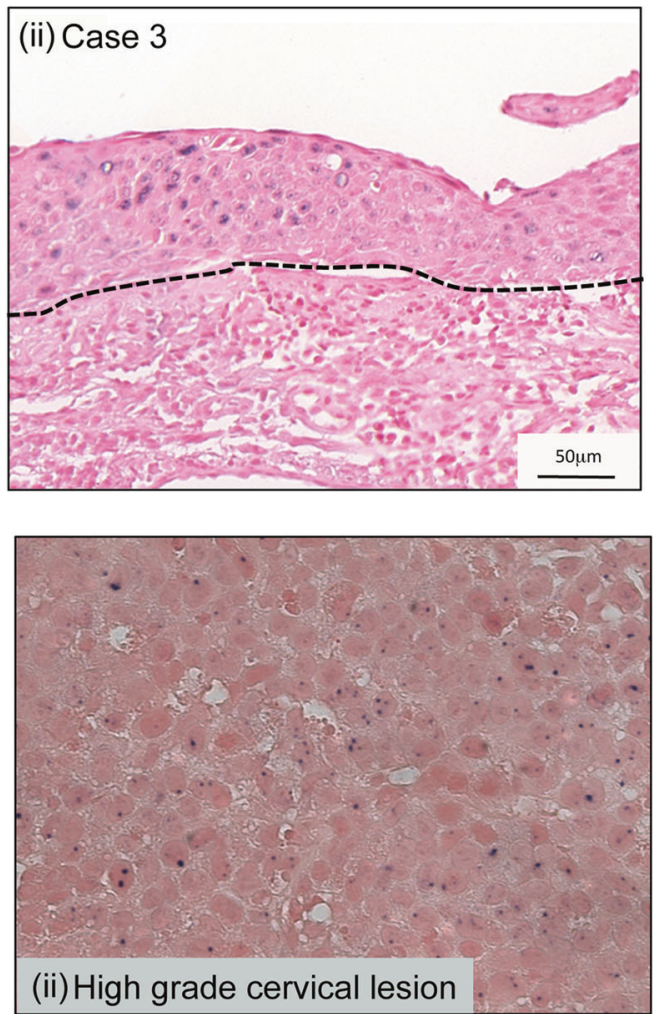

signal intensity towards the epithelial surface (ii). b Typical in situ hybridisation patterns seen in low-grade cervical neoplasia, where some degree of genome amplification is apparently close to the epithelial surface (i), and in high-grade cervical neoplasia (ii) associated with HPV genome integration

As we have detected only one lesion that expressed both the HPV E4 and E6/E7 genes in the mid epithelial layers (the Wing cells) of the conjunctiva, we postulate that productive low-grade lesions may occur rarely at conjunctival sites, and that such low-grade lesions may not be necessary precursors in the development of conjunctival in situ squamous carcinoma. The term carcinoma in situ is now encompassed within the wider term high-grade squamous-intraepithelial lesions, and at the cervix, is generally regarded as a precursor of invasive cervical cancer [24]. Our current thinking is that high-grade squamous-intraepithelial lesions can arise at the endocervix without preceding low-grade squamous-intraepithelial lesions, and that a similar situation may account for the absence of clear precursor lesions that predict the presence of oropharyngeal cancer. In both cases, the particular organisation of the epithelial site where infection occurs is thought to influence viral gene expression and the neoplastic phenotype, with high-grade squamous-intraepithelial lesions being an immediate consequence of virus infection at these sites. As with the tonsils and the endocervix, it seems likely that the conjunctival epithelium may be an epithelial site where viral gene expression is deregulated from the outset. Further investigation of this epithelial site may help us to understand 
the more rapidly progressing high-grade dysplasia at the cervix that can lead to cancer within a few years rather than through a long-term stepwise progression over decades. Interestingly, Scott et al. [25] also suggested an active role for HPV in conjunctival squamous carcinoma, using a PCR (rather than an in situ)-based methodology to detect viral DNA and RNA, although in their case they found positivity in all conjunctival squamous carcinomas. The in situ approach described here support these findings, but suggest that HPV causality extends to only a subset of such lesions, and that these can be characterised by a characteristic pattern of biomarker expression. Interestingly, we also detected three HPV DNA-positive in situ carcinomas with extensive $\mathrm{p} 16^{\mathrm{INK} 4 \mathrm{a}}$ and MCM expression, which were TP53-positive throughout the epithelium. Initially these were thought not to be associated with HPV expression, however they were HPV E6/E7 RNAScope-positive, although with limited expression compared to other HPV DNA-positive conjunctival high-grade squamous-intraepithelial lesions. Upon further examination of the haematoxylin and eosin-stained biopsies we found breakdown of the basal membrane, and extensive lymphocytic infiltration, suggesting some degree of immune control, and an inhibition of viral activity. Indeed, declining HPV E6 expression, as seen by RNAScope transcript mapping, might be expected to reduce the proteosomal degradation of TP53, with $\mathrm{p} 16^{\mathrm{INK} 4 \mathrm{a}}$ and $\mathrm{p} 14^{\mathrm{ARF}}$ rising as a consequence, depending on the cellular microenvironment.

The association between conjunctival in situ squamous carcinoma and atopy has been previously reported by several groups [3, 26, 27]. Rundle et al. [26] noted that relatively young immunocompetent patients present with aggressive disease that is sometimes bilateral and recurrent. There may be several explanations. Atopy is characterised by an allergen-induced elevation of $\operatorname{IgE}$ levels that is mediated by a type- 2 helper $\mathrm{T}$ lymphocyte (Th2 cells) response, with atopic individuals undergoing an exaggerated response following antigen exposure. Although type- 2 responses predominate in neonates, there is usually an immune switch in favour of type-1 responses in normal adults, which supports cell-mediated immunity active against virus-infected and neoplastic cells [28]. As this switch does not occur in atopes, this may explain in part their vulnerability to HPV-infection. Alternatively, changes in barrier proteins such as filaggrin, or the presence of mutations seen in atopic dermatitis, may compromise conjunctival epithelial barrier function [29]. There is also an inverse relationship between the expression of Claudin 1 in tight junctions of the epidermis, and the development of a Th2 response, which suggests that this protein may affect the immune response to putative environmental allergens [30]. Reduced expression of several anti-microbial peptides, including a cathelicidin-LL37 and $\beta$-defensin, has also been reported to predispose to skin infections in atopic dermatitis
[31], along with diminished recruitment of innate immune cells (neutrophils, plasmacytoid dendritic cells, and natural killer cells) which are a critical source of the antiviral type 1 Interferons [32], may further contribute to the susceptibility of atopic individuals to infection.

In this study, the HPV 16-positive atopic group had a higher rate of disease resistance to primary treatment and higher recurrences compared to non-atopic cases that did not harbour HPV 16. Secondly, many of the tumours in the atope group affected the medial, inferomedial, inferior forniceal and inferior tarsal conjunctiva. This is quite different to the classical ultraviolet-induced conjunctival squamous neoplasia that occurs in the sun-exposed conjunctiva at the medial limbus that is often leukoplakic, apparent in the non-atopic group. Whilst speculative, it is possible that atopes may be rubbing their eyes excessively due to the activation of the itch cycle, which is classically induced by cytokine release from eosinophils. In support of this, many of the biopsies from the atopes contained eosinophils. As eye rubbing tends to focus pressure on the medial lower eyelids, it is plausible that the conjunctiva beneath the medial eyelids (medial bulbar, inferior formiceal and inferior tarsal) is being exposed to microtrauma. In support of this proposal, Gichuhi et al. identified micro abrasions of the conjunctival surface caused by vitamin A deficiency as a risk factor in conjunctival squamous cell carcinoma in cases from Africa, potentially allowing HPV to invade the conjunctival epithelial cells [2]. Recently, McGrath et al. recorded their experience of conjunctival squamous carcinoma in patients wearing ocular prostheses [33]. They all occurred in the superior tarsal conjunctiva where the latter was constantly rubbing against an ocular prosthesis. In three out of four of the cases, the conjunctival biopsies from the squamous carcinoma contained HPV16 DNA (by PCR). They proposed that ocular prosthesis-induced conjunctival microtrauma which could be rendering the conjunctiva susceptible to HPV16 infection and conspiring with the effects of direct trauma induced metaplasia to trigger conjunctival squamous carcinoma [33].

At present, it is not known how HPV16 gains access to the conjunctiva. Possible routes of infection include direct inoculation, potential spread from the nasopharnyx via the nasolacrimal duct or haematogenous. The clinical information presented in this paper suggests that a combination of HPV infection and atopy confers an aggressive course, with more resistance to primary treatment and more recurrences compared to non-atopes. However, it was not possible to fully compare the clinical course between atopes with HPV 16 and atopes without HPV16 because of the small number of cases for the latter group.

In summary, the work described here identifies a novel vulnerable epithelial site where HPV16, the most problematic high-risk HPV type, causes conjunctival in situ 
squamous carcinoma. As at the cervix and anus, it appears that conjunctival in situ squamous carcinoma can be associated with a junctional epithelium. We were able to find evidence of late gene expression (HPV E4 protein) in only one case, suggesting that conjunctival in situ squamous carcinoma is most likely, a direct consequence of viral infection in a subset of patients. The molecular deficiency that predisposes atopic individuals to infection and the development of squamous neoplasia warrants further analysis.

Acknowledgements This work was supported in part by the UK Medical Research Council through program grant MC_U117584278 (Molecular Biology of Human Papillomavirus Infection). The authors thank Dr. Kate Cuschieri, Department of Laboratory Medicine, Scottish HPV, Reference Laboratory, Royal Infirmary of Edinburgh, UK for carrying out the initial screening HPV PCR analysis for Cases 1 to 30 .

\section{Compliance with ethical standards}

Conflict of interest The authors declare that they have no conflict of interest.

Publisher's note: Springer Nature remains neutral with regard to jurisdictional claims in published maps and institutional affiliations.

\section{References}

1. Lee GA, Hirst LW. Incidence of ocular surface epithelial dysplasia in metropolitan Brisbane. A 10-year survey. Arch Ophthalmol. 1992;110:525-7.

2. Gichuhi S, Sagoo MS, Weiss HA, Burton MJ. Epidemiology of ocular surface squamous neoplasia in Africa. Trop Med Int Health. 2013;18:1424-43.

3. Heinz C, Fanihagh F, Steuhl KP. Squamous cell carcinoma of the conjunctiva in patients with atopic eczema. Cornea. 2003; 22:135-7.

4. Doorbar J, Quint W, Banks L, Bravo IG, Stoler M, Broker TR, et al. The biology and life-cycle of human papillomaviruses. Vaccine. 2012;30(Suppl 5):F55-70.

5. Isaacson Wechsler E, Wang Q, Roberts I, Pagliarulo E, Jackson D, Untersperger $\mathrm{C}$, et al. Reconstruction of human papillomavirus type 16-mediated early-stage neoplasia implicates E6/E7 deregulation and the loss of contact inhibition in neoplastic progression. J Virol. 2012;86:6358-64.

6. Tornesello ML, Buonaguro L, Giorgi-Rossi P, Buonaguro FM. Viral and cellular biomarkers in the diagnosis of cervical intraepithelial neoplasia and cancer. BioMed Res Int. 2013; 2013:519619.

7. von Knebel Doeberitz M, Reuschenbach M, Schmidt D, Bergeron C. Biomarkers for cervical cancer screening: the role ofp16 (INK4a) to highlight transforming HPV infections. Expert Rev Proteom. 2012;9:149-63.

8. Ikenberg H, Bergeron C, Schmidt D, Griesser H, Alameda F, Angeloni $\mathrm{C}$, et al. Screening for cervical cancer precursors with p16/Ki-67 dual-stained cytology: results of the PALMS study. J Natl Cancer Inst. 2013;105:1550-7.
9. McLaughlin-Drubin ME, Crum CP, Munger K. Human papillomavirus E7 oncoprotein induces KDM6A and KDM6B histone demethylase expression and causes epigenetic reprogramming. Proc Natl Acad Sci USA. 2011;108:2130-5.

10. Doorbar J. Papillomavirus life cycle organization and biomarker selection. Dis Markers. 2007;23:297-313.

11. Moyer AB, Roberts J, Olsen RJ, Chevez-Barrios P. Human papillomavirus-driven squamous lesions: high-risk genotype found in conjunctival papillomas, dysplasia, and carcinoma. Am J Derm. 2018;40:486-90.

12. Afrogheh AH, Jakobiec FA, Hammon R, Grossniklaus HE, Rocco J, Lindeman NI, et al. Evaluation for high-risk HPV in squamous cell carcinomas and precursor lesions arising in the conjunctiva and lacrimal sac. Am J Surg Pathol. 2016;40:519-28.

13. Woods M, Chow S, Heng B, Glenn W, Whitaker N, Waring D, et al. Detecting human papillomavirus in ocular surface diseases. Invest Ophthalmol Vis Sci. 2013;54:8069-78.

14. de Sanjose S, Quint WG, Alemany L, Geraets DT, Klaustermeier JE, Lloveras B, et al. Human papillomavirus genotype attribution in invasive cervical cancer: a retrospective cross-sectional worldwide study. Lancet Oncol. 2010;11:1048-56.

15. Alkatan HA-HC, Croxatto JO, Dubovy S, Eberhart CG, Iacob CE, $\mathrm{Li} \mathrm{B}$, et al. Conjunctival squamous intraepithelial neoplasia. In: Grossniklaus EEC, Kivela TT, editors. WHO classification of tumours of the eye. 4th ed. Lyon: WHO; 2018. 23-5. .

16. Doorbar J, Foo C, Coleman N, Medcalf L, Hartley O, Prospero T, et al. Characterization of events during the late stages of HPV16 infection in vivo using high-affinity synthetic Fabs to E4. Virology. 1997;238:40-52.

17. Griffin H, Soneji Y, Van Baars R, Arora R, Jenkins D, van de Sandt M, et al. Stratification of HPV-induced cervical pathology using the virally encoded molecular marker E4 in combination with p16 or MCM. Mod Pathol. 2015;28:977-93.

18. Griffin H, Wu Z, Marnane R, Dewar V, Molijn A, Quint W, et al. E4 antibodies facilitate detection and type-assignment of active HPV infection in cervical disease. PLOS ONE. 2012;7: e49974.

19. Scheffner M, Huibregtse JM, Vierstra RD, Howley PM. The HPV-16 E6 and E6-AP complex functions as a ubiquitin-protein ligase in the ubiquitination of p53. Cell. 1993;75:495-505.

20. Egawa N, Wang Q, Griffin HM, Murakami I, Jackson D, Mah$\operatorname{mood} \mathrm{R}$, et al. HPV16 and 18 genome amplification show different E4-dependence, with 16E4 enhancing E1 nuclear accumulation and replicative efficiency via its cell cycle arrest and kinase activation functions. PLoS Pathog. 2017;13:e1006282.

21. Redman R, Rufforny I, Liu C, Wilkinson EJ, Massoll NA. The utility ofp16(Ink4a) in discriminating between cervical intraepithelial neoplasia 1 and nonneoplastic equivocal lesions of the cervix. Arch Pathol Lab Med. 2008;132:795-9.

22. van Zummeren M, Leeman A, Kremer WW, Bleeker MCG, Jenkins D, van de Sandt M, et al. Three-tiered score for Ki-67 andp16(ink4a) improves accuracy and reproducibility of grading CIN lesions. J Clin Pathol. 2018;71:981-8.

23. Pathak N, Dodds J, Zamora J, Khan K. Accuracy of urinary human papillomavirus testing for presence of cervical HPV: systematic review and meta-analysis. Br Med J. 2014;349:g5264.

24. Blaustein A, Kurman RJ. Blaustein's pathology of the female genital tract. 6th ed. New York, NY: Springer; 2011. xv, 1246 p.

25. Scott IU, Karp CL, Nuovo GJ. Human papillomavirus 16 and 18 expression in conjunctival intraepithelial neoplasia. Ophthalmology. 2002;109:542-7.

26. Rundle P, Mudhar HS, Rennie I. Conjunctival intra-epithelial neoplasia occurring in young patients with asthma. Eye. 2010; $24: 1182-5$. 
27. Shah A, Espana EM, Singh AD. Ocular surface squamous neoplasia associated with atopic keratoconjunctivitis. Ocul Oncol Pathol. 2017;3:22-7.

28. Donovan CE, Finn PW. Immune mechanisms of childhood asthma. Thorax. 1999;54:938-46.

29. Thyssen JP, Kezic S. Causes of epidermal filaggrin reduction and their role in the pathogenesis of atopic dermatitis. J Allergy Clin Immunol. 2014;134:792-9.

30. De Benedetto A, Rafaels NM, McGirt LY, Ivanov AI, Georas SN, Cheadle C, et al. Tight junction defects in patients with atopic dermatitis. J Allergy Clin Immunol. 2011;127: 773-86 e1-7.
31. Kuo IH, Yoshida T, De Benedetto A, Beck LA. The cutaneous innate immune response in patients with atopic dermatitis. J Allergy Clin Immunol. 2013;131:266-78.

32. Luci C, Gaudy-Marqueste C, Rouzaire P, Audonnet S, Cognet C, Hennino A, et al. Peripheral natural killer cells exhibit qualitative and quantitative changes in patients with psoriasis and atopic dermatitis. Br J Dermatol. 2012;166:789-96.

33. McGrath LA, Salvi SM, Sandramouli S, Bhatt R, Cuschieri K, Mudhar HS Squamous cell carcinoma in the anophthalmic socket: a series of four cases with HPV-16 profiling. Br J Ophthalmol. 2018. https://doi.org/10.1136/bjophthalmol-2018-311916. [Epub ahead of print] 